\title{
Arabic Loanwords in Tatar and Swahili: Morphological Assimilation
}

\author{
Aida R. Fattakhova ${ }^{1} \&$ Nailya G. Mingazova ${ }^{1}$ \\ ${ }^{1}$ Kazan (Volga region) Federal university, Kazan, Russia \\ Correspondence: Nailya G. Mingazova, Kazan (Volga region) Federal university, Kremlyoskaya Street, 18, \\ Kazan 420008, Russia. E-mail: nailyahamat@mail.ru
}

Received: April 14, 2015 Accepted: April 20, 2015 Online Published: April 27, 2015

doi:10.5539/jsd.v8n4p302

URL: http://dx.doi.org/10.5539/jsd.v8n4p302

\begin{abstract}
This article deals with the analysis of the morphological assimilation of Arabic loanwords into Tatar, Altai language family, and Swahili, Bantu language family. The urgency of this review is caused by the fact that the formation of both Tatar and Swahili was influenced by Arabic, which had profoundly influenced them in religious, scientific, cultural and economic aspects. In this paper we apply the comparative approach that is aimed at finding isomorphic and allomorphic features in the languages studied and identifying their peculiarities in the process of Arabic vocabulary assimilation. The morphological assimilation of Arabic loanwords into these languages is realized by verbal nouns, participles, nouns denoting place and action. One of the isomorphic features of the recipient languages is the absence of the category of gender both in Tatar and Swahili; among the allomorphic peculiarities are postposition of adjectives after nouns in Swahili and the use of compound verbs with Arabic nouns as their stems in Tatar. The results of the research will contribute to the loanword studies in these unrelated languages.
\end{abstract}

Keywords: Arabic loanwords, morphological assimilation, isomorphic and allomorphic features, Tatar, Swahili

\section{Introduction}

Every language changes as time passes. Language contact as a worldwide sociolinguistic phenomenon influences this process as well. One of this contact results is lexical borrowing. Moreover, as M. A. Al Btoush asserts, in order to cope with innovations and new experiences and discoveries the language needs loanwords which can cover up-to-date concepts and any new ideas (Al Btoush, 2014).

The loanwords of different languages have been studied from various perspectives. Basem I. M. Al-Raba'a's paper is concerned with the structural borrowing from English to Arabic in translation (Al-Raba'a, 2013). Kwasi Adomako analyzes underapplication of the phonological process in Akan in the domain of loanword adaptation (Adomako, 2013). M. A. Al Btoush explores English loanwords and the reasons behind their increase in the daily Jordanian speech (Al Btoush, 2014).

As for loanword studies in Tatar and Swahili, they are mostly based on revealing donor-languages and analyzing loanword phonological and morphological changes. Thus, G.Kh. Akhatov compared the usage of lexical loanwords in the Tatar language (Akhatov, 1979). F.S. Safiullina analyzed the phonological and morphological assimilation of Arabic-Persian loanwords into Tatar (Safiullina, 1999). I.I. Siraziyev studies Arabic loanwords in modern Tatar (Siraziyev, 2002).

First scientific attempts to Swahili studies began in the middle of the XIX century. As Thilo C. Schaderberg points out, the Swahili database is based on the perusal of dictionaries and loanword studies (Schadeberg, 2009). L. Krapf (1882) and E. Steer (1884) started the documentation of Swahili lexicon and grammar. A. Madan (1931), F. Jonson (1939), Ch. Sacleux (1939), B. Krumm (1940), E. Ashton (1956) contributed in this field (Myachina, 1960). Zawawi (1976) analyzed the Arabic loanwords and claimed some interesting etymologies for Swahili words of Bantu origins. Batibo H.M. (1996) compared nativized English loanword clusters in Tswana and Swahili and emphasized the expansion of lexical stock to respond to technical, scientific and educational demands (Batibo, 1996). In his research Th. C. Schaderberg (2009) highlights contact situations in the Indian Ocean territory: Swahili as a contact language and donor languages throughout its history, Arabic being the most important among them (Schadeberg, 2009). 


\section{Methodological Framework}

Our research aimed at comparing the morphological assimilation of Arabic loanwords into Tatar and Swahili. This article reveals the morphological peculiarity of the Arabic loanwords included in both active and passive lexicon of languages studied. The comparative analysis is aimed at finding isomorphic and allomorphic features in both languages and identifying the peculiarities of these unrelated languages in the process of Arabic vocabulary assimilation.

\section{Results}

\subsection{The Analyses of Arabic Loanwords in Tatar and Swahili}

The formation of both Tatar and Swahili was influenced by Arabic, which had profoundly influenced them in religious, scientific, cultural and economic aspects. Both languages used the Arabic script. The change from Arabic script to the Russian alphabet in the Tatar language and to the Latin alphabet in Swahili served as one of the reasons for the gradual fading away of Arabic words and their replacement by native words. Thus, the vocabulary of modern Tatar language has lost a huge number of Arabic loanwords that had been actively used in fiction and scientific literature before the beginning of the XX century. Some Arabic lexical units have been strongly transformed and, accept by intuition, they wouldn't be able to be identified in the recipient languages. For example, the Arabic proverbiwa'du-l-hurri dain] "the promise of a noble is a debt of honour" functions in Swahili with a low degree of borrowing identification: Ahidi ni deni "The promise is a debt".

Swahili, a Bantu family language, and Tatar, an Altai family language, are both agglutinative languages. Therefore, there should be a general tendency toward Arabic word assimilation.

While analyzing loanwords in Swahili Th. C. Schaderberg asserts that throughout its history, Swahili has been a contact language... the adoption of numerous loanwords occurred... (Schadeberg, 2009). It is well known that Arabic has always been in contact with other languages throughout history. It has been the most important donor language in the Indian Ocean trading network as well... the variety of Arabic that served as a lingua franca for that region has itself been enriched by borrowings from those languages. As a result, many etymons can be found in more than one of the languages involved, and it is not always possible to identify the immediate donor language of a particular loan word in Swahili. Moreover the linguist describes Swahili as a Bantu language with many Arabic terms... (Schadeberg, 2009).

It is obvious that Swahili in contrast to other Bantu languages has been strongly influenced by Arabic especially its vocabulary. So, more than half of class 9 nouns are Arabic loanwords, such as saa "a clock, watch" (ساعة [saa'a]). As Gromova N.V. and Okhotina N.V. point out these nouns are not assimilated with the help of prefixes what is rare for loanword assimilation in Swahili, eg. akili "mind" (عقل [aql]). Moreover, all borrowed words with unvoiced consonants at their beginning are the part of this noun class because it's one of noun class 9 characteristics: along with its prefixes $n$-, $n y$-, $m$ - it has a zero one before unvoiced consonants, eg. sanduku "a box" (صندوق [sunduuq]) (Gromova, Okhotina, 1995). Among the Arabic loanwords are different parts of speech: nouns, verbs, adjectives, numerals, prepositions, conjunctions. They are of diverse semantic fields: navigation, trade, jurisprudence, science, culture, vegetation, the house, etc.

Arabic lexical units, absorbed into Tatar and Swahili, brought their own morphological forms; they were also influenced by the grammatical rules of the recipient language, as reflected in the new morphological indicators.

Among the most active loanwords in Tatar and Swahili are nouns. They are abstract concepts:

\begin{tabular}{|c|c|c|c|}
\hline Arabic & Swahili & Tatar & meaning \\
\hline ['aql] عقل & akili & акыл [akyl] & "mind" \\
\hline حمـة [hikma(t)] & hekima & хикмәт [hikmət] & "wisdom" \\
\hline \multicolumn{4}{|l|}{ proper names: } \\
\hline Arabic & Swahili & \multicolumn{2}{|c|}{ Tatar } \\
\hline محد [muhammad] & Mohammed & \multicolumn{2}{|c|}{ Мөхәммәд [mehəmməd] } \\
\hline ]'ali] علي & Ali & \multicolumn{2}{|c|}{ Гали $[$ gali $]$} \\
\hline
\end{tabular}


words denoting persons:

\begin{tabular}{c|c|c|c}
\hline Arabic & Swahili & Tatar & meaning \\
\hline [سكريّ ['askarii] & askari & гаскәри [gaskəri] & "military" \\
[قير [fakyir] & fakiri & факыйрь [fakyir] & "poor" \\
\hline
\end{tabular}

Religious terminology is considered to be a separate branch of borrowings apart from Arabic ones. So, Th. C. Schaderberg concludes that in the XII or XIII century Swahili society adopted Islam as its dominant religion... and opened itself to Arab poetry, music, learning and way of life - adapting and integrating these and other foreign elements with local values and thus creating a unique Swahili culture... the influence of Arabic and Islam continues until today (Schadeberg, 2009). Basem I. M. Al-Raba'a emphasizes that the status of Arabic as a superimposed language after it was established as the new cultural, administrative, and religious language of the Islamic empire did not make it impenetrable to the effect of other cultures (Al-Raba'a, 2013). For example:

\begin{tabular}{|c|c|c|c|}
\hline Arabic & Swahili & Tatar & meaning \\
\hline ] [muslim] مسلم & maislamu & мөселман [meselman] & Muslim \\
\hline [mu'azzin] & muezzin & мөәзин [meəzin] & muezzin \\
\hline \multicolumn{4}{|c|}{ words denoting natural phenomena: } \\
\hline Arabic & Swahili & Tatar & meaning \\
\hline فfajr] فجر & alfajiri & фәжере [fəjr] & dawn \\
\hline هواء [hawa] & hewa & hава [hawa] & air \\
\hline \multicolumn{4}{|l|}{ objects: } \\
\hline Arabic & Swahili & Tatar & meaning \\
\hline [saabuun] & sabuni & сабын [sabyn] & soap \\
\hline دواء [dawa'] & dawa & дәва [dəwa] & medicine \\
\hline \multicolumn{4}{|c|}{ words expressing time concepts: } \\
\hline Arabic & Swahili & Tatar & \\
\hline ساعة [sa'at] & $s a a$ & cәгаmь $[\mathrm{s} \partial g a t]$ & vatch, clock \\
\hline وقت & wakati & вакыт [wakyt] & \\
\hline \multicolumn{4}{|c|}{$\begin{array}{l}\text { Th. C. Schaderberg considers the most numerous Arabic loanwords being of religion and belief }(47,5 \%) \text {, } \\
\text { possession }(41,4 \%) \text { and law }(41,1 \%) \text { semantic fields. The other semantic groups are ranging from } 5,8 \% \text { to } 40,6 \% \\
\text { of all Swahili words (Schadeberg, 2009). There are more adjectives and nouns among them. ...Swahili has } \\
\text { borrowed "adjectival concepts" with relative ease (Schadeberg, 2009). }\end{array}$} \\
\hline \multicolumn{4}{|c|}{$\begin{array}{l}\text { Most Arabic loanwords entered Tatar and Swahili in so-called "pause form" when there is a pause or stop at the } \\
\text { end of the word and final short vowel case inflections, suffixed to the noun, as well as suffix - } n \text { (so-called } \\
\text { [tanween] "nunation") are not pronounced in speech. For example: }\end{array}$} \\
\hline Arabic & Swahili & Tatar & meaning \\
\hline كتاب [Kitaab(un)] & кitabu & кuman [kitap] & a book \\
\hline [hisaab(un)] & hesabu & xucan [hisap] & calculation \\
\hline شرط [shart(un)] & sharti & mapm [shart] & condition \\
\hline
\end{tabular}

\subsection{The Analyses of Arabic Words' Assimilation into Tatar and Swahili}

The analysis of the Arabic loanwords was carried out taking into account the morphological peculiarities of Arabic as a donor language and the words' assimilation into Tatar and Swahili as recipient languages.

1. The Arabic verbs came to Swahili in their basic forms in the same function, the most active being the [fa'ala] pattern. For example:

-samehe (سمح [samaha]) “to forgive", -hesabu (حسب [hasaba]) "to count", -shiriki (شرك [sharika]) "to take part", etc. The markers of the Arabic loanwords are the suffixes $-\mathbf{e},-\mathbf{- i},-\mathbf{u}$. 
These loanwords follow the grammatical rules of Swahili. Thus, directive meaning of the verb is conveyed with the help of adding the causative suffix -sha (-ya) to the basic form (in Arabic the فfala] pattern that is formed by the gemination of the second stem letter is used in this case). For example:

-rudisha "to return", "to give back" (rudi "to come back"), -safirisha "to transport" (-safiri "to travel"), etc.

Among the other Arabic forms only the تفعَ "tafa"'ala] pattern is widely spread in Swahili, for example: -taadabu “to be polite" (تأدبّ [ta'addaba]), -tafakari "to ponder over" ( تفكّر [tafakkara]), -taahari "to be late" (تأخّرَ [ta' ahhara]), etc.

In contrast to Swahili, the Arabic verbs are not used in the basic form in Tatar. Their meaning is conveyed by derived verbs formed with the help of suffixes or by compound verbs formed by adding auxiliary verbs. In this case Arabic nouns, verbal nouns, participles, and adjectives are used as the basic form of these borrowed verbs. In the suffixed way of forming verbs, the suffixes -ла, -лә [-1a, -lə] are most frequently involved, for example: хөрмәтлә [hөrmətlə] "show respect", фикерлә [fikerlə] "think", зарарла [zararla] "damage", etc. Compound verbs are formed by adding the auxiliaries umY [itu] "to do", бирY [biru] "to give", кылу [kylu] "to fulfill", etc.

So, the assimilation of some Arabic borrowed verbs in Tatar and Swahili can be presented in the following table:

\begin{tabular}{|c|c|c|c|}
\hline Arabic & Tatar & Swahili & meaning \\
\hline [sabara] & сабыр итү [sabyr itu] & subiri & to tolerate \\
\hline [rahhasa] رخّص & pөхсәт биру (umy) [rehsət biru(itu)] & ruhusu & to allow, to permit \\
\hline ] أجاب ['ajaaba] & ж⿻авап бирү [javap biru] & jibu & to answer \\
\hline
\end{tabular}

As it can be seen from these examples, the Arabic verbs in Swahili are used in their original form, and in Tatar they are compound verbs.

2. The most numerous Arabic loanwords are presented by verbal nouns (so-called masdars), denoting action or state. The similar grammatical form exists in Tatar [isem figyl] as a part of verbs, and in contrast to Arabic, it has the characteristics of verbs (Zakiev, 1993). In Swahili, borrowed Arabic verbal nouns possess nominal characteristics. There are special patterns of verbal nouns for each verb pattern in Arabic. The most numerous borrowed verbal nouns are those of the فعل [fa'ala] pattern. For example:

\begin{tabular}{c|c|c|c}
\hline Arabic & Tatar & Swahili & meaning \\
\hline سؤال [su'aal] & сөаль [сөәл] & swali & question \\
[fikr] & фикер [fiker] & fikira & thought \\
\hline
\end{tabular}

There are the following widely spread patterns of the verbal nouns in the languages studied:

\begin{tabular}{|c|c|c|c|c|}
\hline verb patterns & Arabic & Tatar & Swahili & meaning \\
\hline [fa'’ala] & تأثير [ta'athiir] & тәэсир [təəsir] & taathira & influence \\
\hline فاعل [faa'ala] & معاملة [mu'aamala] & мөгамдлә[megəmələ] & muamala & attitude \\
\hline ['af'ala] & 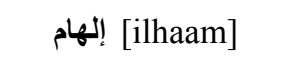 & илhам [ilham] & ilhamu & inspiration \\
\hline [tafa"'ala] & [takabbur] & тәкәбберлек [təkəbbərlek] & takaburi & arrogance \\
\hline تفاعل [tafa'ala] & ] توازن ] tawaazun] & тәвазен [təvəzen] (outdated) & - & balance \\
\hline [infa'ala] & ] [insaaf] & инсаф [insaf] & insafu & justice \\
\hline [ifta'ala] & [imtihaan] & имтихан[imtihan] & mtihani & exam \\
\hline [istaf'ala] & [istiraaha] & истирахәт [istirahət] (outdated) & starehe & rest \\
\hline
\end{tabular}

As it is clear from the table, the Arabic verbal noun is used in its basic grammatical form in the recipient languages with some phonetic changes as a result of specific Arabic phoneme assimilation. Most verbal nouns are substantivized and acquire morphological markers of nouns and change in case, number, and etc.

3. The other most widely-spread borrowed grammatical forms in Tatar and Swahili are Arabic active and passive participles. Some active participles are subtantivized and function as nouns, for example: мөхәррир [mehərrir] mhariri "an editor" (محرّ [muharrir] "releasing, an editor"), мөгаллим [mөgallim] - mwalimи "a teacher" (معلّ [mu'allim] "teaching, a teacher"), etc. This process is connected with the peculiarity of Arabic active participles that possess nominal characteristics.

The most productive borrowed active participles of the فع [fa'ala] pattern. The verb pattern jeفع' [if'alla] with its basic meaning "to become of certain colour or acquire some quality" (Grande, 1998) was not borrowed by the 
languages studied. It explains the absence of borrowed active participles of the [if'alla] pattern in Tatar and Swahili. Here are the examples of borrowed active participles of different verb patterns:

\begin{tabular}{|c|c|c|c|c|}
\hline verb patterns & Arabic & Tatar & Swahili & meaning \\
\hline فعل [fa'ala] & كافر [kaafir] & кяфир [kyafir] & kafiri & unbelieving \\
\hline [fa"'ala] & معلّم [mu'allim] & мөгаллим [megallim] & mwalimu & teaching \\
\hline فاعل [faa'ala] & ] [muaafiq] موافق & муафыйк [muafyiq] & mwafaka & accepting \\
\hline ['af'ala] & مدير [mudiir] & мөдир $[$ mөdir $]$ & mudir $[i]$ & managing \\
\hline تفعّل [tafa"'ala] & متحرّك & мөтәхәррик (yст.) [mөtəhərrik] & - & moving \\
\hline تفاعل [tafa'ala] & متشارك [mutashaarik] & мөтәшарик (уст.) [mөtәsharik] & - & taking part \\
\hline [infa'ala] & منكاشف [munkashif] & мөнкәшиф [mөnkəshif] & - & discovered \\
\hline [ifta'ala] & [muhtaaj] & мохтаж⿻ [mohtaj] & mhitaji & needy \\
\hline [istaf'ala] & [mustaqill] & мөстәкыйль [mөstəqyil] & - & independent \\
\hline
\end{tabular}

As for borrowed passive participles, they are not as numerous in the languages studied and mostly presented by those of the فfa'ala] pattern. For example:

\begin{tabular}{c|c|c|c}
\hline Arabic & Tatar & Swahili & meaning \\
\hline مشهور [mashhuur] & мәшһһр [məshhur] & mashuhuri & famous \\
مطوم [ma'luum] & мәгъл Yм [məglym] & maalum & definite \\
\hline
\end{tabular}

4. The Arabic qualitative and relative adjectives with the suffix ${ }^{3}$ [ij] are used in Tatar and Swahili, but in some cases they have different meanings. For example:

\begin{tabular}{c|c|c|c|c}
\hline Arabic & Tatar & meaning & Swahili & meaning \\
\hline عزيز['ziiz] & газиз [gaziz] & dear & $a z i z i$ & darling \\
كامل [kaamil] & калил [kamil] & perfect & $k a m i l i$ & finished \\
مصريّ [misrij] & - & Egyptian & misri & Egyptian \\
إقتصاديّ [iqtisadij] & икътисади [iktisadi] & economic & - & - \\
\hline
\end{tabular}

The borrowed qualitative adjectives in Tatar are mostly substantivized, for example: axмaк [ahmaq] "fool" from Arabic أحمق ['ahmaq] "foolish", etc.

The borrowed adjectives in Swahili don't have special markers as in Arabic and, in contrast to Tatar, are in postposition after nouns, for example: sahani safi "a clean plate", etc.

5. The similar characteristic of both Tatar and Swahili is the absence of the category of gender. The Arabic

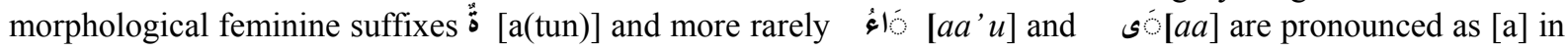
Swahili and as [ə] or [a] in Tatar. For example:

\begin{tabular}{|c|c|c|c|}
\hline Arabic & Tatar & Swahili & meaning \\
\hline [daraja(tun)] درجة & дәрәжə઼ [dərəjə] & daraja & level \\
\hline معنى [ma'naa] & мәгънә [məgnə] & maana & meaning \\
\hline فائدة [faa'ida(tun)] & файда [faida] & faida & benefit \\
\hline
\end{tabular}

Unlike Swahili, in Tatar there are loanwords assimilated with their own feminine markers function as [at] or [ət]. For example:

\begin{tabular}{c|c|c|c}
\hline Arabic & Tatar & Swahili & meaning \\
\hline صورة [suura(tun)] & cypəm $[$ surət] & sura & appearance \\
لغة [luga(tun)] & лөгəmb $[$ legət] & lugha & language \\
ساعة [saa'a(tun)] & cәzamb $[$ səgat] & saa & time, watch, clock, o'clock \\
\hline
\end{tabular}

The same characteristic can be traced in the following borrowed proverb: Хәрәкәттә - бәрәкәm [hərəkəttə bərəkət] "Movement is divine grace" (في الحركة بركة [fi al-haraka - baraka]). In Swahili this proverb has additional shade of meaning: Haraka haraka haina baraka "there is no divine grace in hurrying".

The Arabic category of gender influenced Tatar. So, nouns denoting occupation have gender differences, for 
example: шагыйрь [shagir] "poet" - шагыйрә [shagirə] "poetess", галим ['alim] "male scientist" - галимә ['alimə] "female scientist", etc. In Swahili only the masculine form is used for denoting both masculine and feminine genders, for example: mwalimu - "teacher", mhudumu - "waiter, waitress", mudir [i] - "manager", etc.

6. There are two plural categories in Arabic: Broken Plurals, that are formed by shifting the consonants into different vowel patterns so that the syllabic structure of the word changes, and Sound Plurals (Masculine and Feminine), that are formed by adding plural suffixes: ون [uuna] for masculine and 1 [aat(un)] for feminine (Mingazova, 2014). In Tatar, both Arabic plural categories are borrowed, the Sound Feminine plural form being the most productive, for example: әдәбияm [ədəbiyaat] "literature", нәшрияm [nəshriyaat] "press", etc. In Swahili this form is rare: maakulati "food".

Until the first half of the XX century, Tatar vocabulary had a huge number of Arabic loanwords in broken plural forms: әзвәжс [әzиәj] "husband and wife", мәваид [məuaid] "set table", etc. These words have faded away and have been replaced by Tatar, Russian, or foreign words (Siraziyev, 2002).

Apart from Tatar, the category of number in Swahili is not separated from the class system of nouns. Singular class nouns correlate with plural class nouns (Gromova, Okhotina, 1995). This peculiarity of plural class markers is in a way similar to the Arabic Broken plural forms that have more than ten different patterns (Mingazova, 2014). Mostly all borrowed loanwords in Swahili acquire Swahili plural class markers: rafiki "friend" - marafiki "friends", shaka "doubt" - mashaka "doubts", kitabu "book" - vitabu "books", and etc. Some of them don't change in number: matini "a text, texts"; hadithi "story, stories"; hatua "a step, steps"; kalamu "a pen, pens", etc. In Tatar on the contrary some Arabic plural forms are used in the singular meaning: أعضاء ['a'daa'] "members" әгъзә [әgzə] "a member", أسباب ['asbaab] "belongings" - әсбәл [әsbəp] "an object of belongings" (Siraziyev, 2002).

In Swahili, there is a borrowed plural form that is used in the singular meaning: baharia "a sailor" (from Arabic [طaيّة - بحريّ [bahrijya] "sailors") that changes in number: baharia "a sailor" - mabaharia "sailors".

7. So-called nouns denoting place and action of the مفعل [maf'al] or مفع [maf'il] patterns sometimes adding the feminine suffix $\ddot{\partial}$ [a(tun)] are borrowed as well both in Tatar and Swahili:

\begin{tabular}{c|c|c|c}
\hline Arabic & Tatar & Swahili & meaning \\
\hline محكمة [mahkama] & мәхкәмә [məhkəтә] & mahakama & court \\
مدرسة [madrasa] & мәдрәсә [mədrəsə] & madrasa & madrasah \\
مسرح [masrah] & - & masirahi & theatre
\end{tabular}

In Swahili these words, as a rule, are used in the plural meaning.

8. There are some borrowed Arabic set phrases in the languages studied:

- praying exclamations that are used as interjections:

\begin{tabular}{ccccc}
\hline Arabic & Tatar & Swahili & meaning \\
\hline ما شاء الله [ma sha'a allah] & мамаала [mashalla] & mashalla & It's great! \\
إن شاء الله $[$ in sha'a allah] & инша алла [insha alla] & inshallah & God willing! \\
\hline
\end{tabular}

- In Swahili there is a case of borrowing preserving the morphological markers of the categories of person, gender and number: $a[h]$ sante "thank you" from the Arabic أحسنت [ahsanta] "you (masculine, singular) did it greatly" in the meaning of "bravo, wonderful".

\section{Discussions}

The loanwords of different languages have been recently studied by different scholars: Basem I. M. Al-Raba'a (2013), Kwasi Adomako (2013), M. A. Al Btoush (2014), etc. Arabic loanwords in Tatar have been analyzed by G.Kh. Akhatov (1979), F.S. Safiullina (1999), I.I. Siraziyev (2002), etc. Arabic loanwords in Swahili have been studied by Zawawi (1976), Th. C. Schaderberg (2009), etc. This paper presents the first attempt to compare the morphological assimilation of Arabic loanwords into both Tatar and Swahili applying the comparative approach.

\section{Conclusion}

So, the analysis of the morphological assimilation of Arabic loanwords into Tatar and Swahili has revealed the following peculiarities: 
1. The morphological assimilation of Arabic loanwords into languages studied is realized by different grammatical forms of the donor language: verbal nouns, participles, nouns denoting place and action, etc.

2. In Arabic words' assimilation the isomorphic features of recipient languages were observed: assimilation of words in so-called "pause form"; the absence of the category of gender both in Tatar and Swahili; substantivizing process of Arabic verbal nouns and active participles, etc.; as well as allomorphic peculiarities were traced. In Swahili: the borrowing of the broken plural form; the use of verbs in Arabic basic forms; postposition of adjectives after nouns; the usage of singular nouns denoting place and action in the plural meaning. In Tatar: the use of compound verbs with Arabic nouns as their stems; the influence of Arabic on the category of gender.

The analysis of Arabic loanwords reveals the essence of language borrowing process as a result of cross-cultural communication between different ethnic and language groups.

\section{Acknowledgments}

The work is performed according to the Russian Government Program of Competitive Growth of Kazan Federal University

\section{References}

Akhatov, G. Kh. (1979). Leksikologiya sovremennogo tatarskogo yazyka. Kazan.

Al Btoush, M. A. (2014). English Loanwords in Colloquial Jordanian Arabic. International Journal of Linguistics, 6(2). http://dx.doi.org/10.5296/ijl.v6i2

Al-Raba'a Basem, I. M. (2013). The Grammatical Influence of English on Arabic in the Passive Voice in Translation. International Journal of Linguistics, 5(1). http://dx.doi.org/10.5296/ijl.v5il

Batibo, H. M. (1996). Loanword clusters nativization rules in Tswana and Swahili: A comparative study. South African Journal of African languages, 16(2), 33.

Grande, B. M. (1998). Kurs arabskoy grammatiki v sravnitelno-istoricheskom osveschenii (2nd ed.). Moscow: Oriental Literature, Russian Academy of Sciences.

Gromova, N. V., \& Okhotina, N. V. (1995). Teoreticheskaya grammatika yazyka Swahili. Moscow.

Kwasi Adomako. (2013). Underapplication in Akan Loanword Adaptation. International Journal of Linguistics, 5(5). http://dx.doi.org/10.5296/ijl.v5i5

Mingazova, N. G., \& Shangaraeva, L. F. (2014). Comparative study of number and case categories in English, Tatar and Arabic. International Journal of Linguistics, l6(1), 26-33. http://dx.doi.org/10.5296/ijl.v6i1

Mingazova, N. G., Subich, V. G., \& Shangaraeva, L. F. (2014). The verb-noun agreement in English and Arabic. Journal of Language and Literature, 5(2), 43-50. http://dx.doi.org/10.7813/j11.2014/5-3/8

Myachina, E. N. (1960). Yazyk Swahili. Moscow.

Safiullina, F. S. (1999). Hezerge tatar edebi tele. Leksikologiya. Kazan.

Schadeberg, Th. C. (2009). Loanwords in Swahili. In A comparative handbook, Loanwords in the world's languages (pp. 77-90). Germany. http://dx.doi.org/10.1515/9783110218442.76

Siraziyev, I. I. (2002). Arabskiy plast leksiki sovremennogo tatarskogo literaturnogo yazyka (Unpublished candidate's thesis). Kazan.

Zakiev, M. Z. (1993). Tatarskaya grammatika. Morphologiya (Vol. 2). Kazan.

\section{Copyrights}

Copyright for this article is retained by the author(s), with first publication rights granted to the journal.

This is an open-access article distributed under the terms and conditions of the Creative Commons Attribution license (http://creativecommons.org/licenses/by/3.0/). 